Acta Universitatis Wratislaviensis No 3799

DOI: $10.19195 / 0524-4544.324 .10$

\author{
MACIEJ BŁAŻEWSKI \\ Uniwersytet Wrocławski \\ maciej.blazewski@uwr.edu.pl
}

\title{
Ograniczenie wolności budowlanej w ujęciu rozporządzenia Prezydenta RP z 1928 r. o prawie budowlanem i zabudowaniu osiedli
}

\section{Wstęp}

Prawo budowlane, po odzyskaniu niepodległości przez Rzeczpospolitą Polską w 1918 r., było zróżnicowane. Na terenie każdego z byłych zaborów obowiązywały odrębne przepisy prawa budowlanego ${ }^{1}$, uwzględniające swoistą kulturę budowlaną ${ }^{2}$. Polskie prawo budowlane, czyli regulacje dotyczące procesu budowlanego w prawie polskim, mające swoje źródło w regulacjach państw zaborczych, było kilkakrotnie nowelizowane. Nowelizacje dotyczyły części sektora budownictwa $^{3}$. Dopiero Rozporządzenie Prezydenta Rzeczypospolitej z dnia 16 lutego 1928 r. o prawie budowlanem i zabudowaniu osiedli ${ }^{4}$ zawierało kompleksową i jednolitą dla całego kraju regulację dotyczącą prawa zagospodarowania przestrzennego oraz prawa budowlanego ${ }^{5}$.

${ }^{1}$ S. Jędrzejewski, Proces budowlany. Zagadnienia administracyjno-prawne, Bydgoszcz 1995, s. 11; L. Bar, Podstawowe zasady prawa budowlanego, Warszawa 1963, s. 6-7; D. Sypniewski, Nadzór nad procesem budowlanym, Warszawa 2011, s. 149; H. Kisilowska, D. Sypniewski, Prawo budowlane, Warszawa 2012, s. 17.

${ }^{2}$ L. Bar, op. cit., s. 7.

${ }^{3}$ D. Sypniewski, op. cit., s. 149; H. Kisilowska, D. Sypniewski, op. cit., s. 17-18.

${ }^{4}$ Rozporządzenie Prezydenta Rzeczypospolitej z dnia 16 lutego 1928 r. o prawie budowlanem i zabudowaniu osiedli (Dz.U. $1928 \mathrm{Nr} 23$, poz. 202) (dalej jako: r.p.b.z.o.).

${ }^{5}$ S. Jędrzejewski, op. cit., s. 12; W. Szwajdler, Prawne problemy procesu budowlanego, [w:] W. Szwajdler, T. Bąkowski, Proces inwestycyjno-budowlany. Zagadnienia administracyjno-prawne, Toruń 2004, s. 130; D. Sypniewski, op. cit., s. 149; H. Kisilowska, D. Sypniewski, op. cit., s. 18. 
Przepisy wyrażone w tym rozporządzeniu miały na celu zapewnienie swobodnego wykonania obiektów budowlanych. Swoboda ta, oznaczająca wolność budowlaną, miała jednak charakter względny, ponieważ była ograniczona przez ochronę interesu publicznego oraz interesu prawnego osób trzecich. Ograniczenia te obejmowały dwie sfery wolności budowlanej: dotyczącej rozpoczęcia oraz organizacji procesu budowlanego ${ }^{6}$.

Ograniczenia wolności budowlanej, wyrażone w tym rozporządzeniu, były zróżnicowane, odrębnie regulowały proces budowlany na obszarze wsi oraz w miastach ${ }^{7}$. Prawo budowlane dopuszczało odstępstwa ze względu na szczególne lokalne uwarunkowania społeczno-gospodarcze. Organy administracji publicznej mogły wydawać miejscowe przepisy budowlane ${ }^{8}$. Rozporządzenie Prezydenta RP zawierało obszerne, kazuistyczne regulacje dotyczące procesu budowlanego 9 . Regulacje miały charakter norm minimalnych, zapewniających bezpieczeństwo ogniowe oraz zdrowia publicznego ${ }^{10}$.

Celem tego opracowania jest określenie zakresu wolności budowlanej oraz ograniczeń tej wolności związanych z potrzebą ochrony, w pierwszej kolejności, interesu publicznego, a w drugiej — także interesu indywidualnego osób trzecich.

\section{Ochrona interesu publicznego oraz interesu prawnego osób trzecich jako cel ograniczenia wolności budowlanej}

Jedną z podstawowych zasad prawa wyrażoną w rozporządzeniu Prezydenta RP była zasada wolności budowlanej, której podmiotem był inwestor określony w tym akcie jako osoba interesowana ${ }^{11}$. Inwestorem był podmiot inicjujący proces budowlany — przez złożenie wniosku o pozwolenie na budowę lub zgłoszenie budowy. Wolność budowlana oznaczała możliwość wykonania robót budowlanych oraz realizacji obiektu budowlanego, w granicach określonych przepisami prawa. Wolność budowlana dotyczyła dwóch sfer procesu budowlanego: jego rozpoczęcia i organizacji. Źródłem wolności budowlanej było prawo własności nieruchomości gruntowej ${ }^{12}$. Osoba interesowana mogła rozpocząć oraz zorganizować proces budowlany

${ }^{6}$ Proces budowlany uregulowany w rozporządzeniu obejmował czynności prawne oraz techniczne wykonywane m.in. przez inwestora oraz inne podmioty tego procesu.

${ }^{7}$ W. Brzeziński, Polskie prawo budowlane, Warszawa 1955, s. 6; L. Bar, op. cit., s. 7; S. Jędrzejewski, op. cit., s. 12.

${ }^{8}$ W. Brzeziński, op. cit., s. 32; C. Krawczak, Prawo budowlane na ziemiach polskich od połowy XVIII wieku do 1939 roku, Poznań 1975, s. 124.

9 W. Brzeziński, op. cit., s. 21; L. Bar, op. cit., s. 8.

${ }^{10}$ W. Brzeziński, op. cit., s. 21; C. Krawczak, op. cit., s. 124.

11 Zob. W. Brzeziński, op. cit., s. 32.

12 Ibidem. 
w granicach regulacji prawa budowlanego, które miały na celu ochronę interesu publicznego oraz interesu indywidualnego, czyli interesu prawnego osób trzecich ${ }^{13}$.

Przepisy prawa nie przewidywały jednak równomiernej ochrony tych interesów. Rozporządzenie Prezydenta RP zapewniało prymat interesu publicznego nad interesem indywidualnym ${ }^{14}$.

Interes publiczny obejmował ochronę: bezpieczeństwa, spokoju, porządku publicznego ${ }^{15}$, bezpieczeństwa pożarowego, zdrowia publicznego oraz estety$\mathrm{ki}^{16}$. Interes ten był wyrażony w regulacjach dotyczących rozpoczęcia oraz organizacji procesu budowlanego, które miały charakter względny. Przepisy prawa dopuszczały odstępstwa od warunków technicznych na określonych obszarach. Odstępstwami tymi były miejscowe przepisy budowlane, które przystosowywały te warunki do lokalnej specyfiki, odpowiadającej uwarunkowaniom społeczno-gospodarczym, w tym możliwościom finansowym miejscowej społeczności oraz kwalifikacjom osób wykonujących roboty budowlane ${ }^{17}$. Odstępstwa miały na celu ponowne wyważenie zakresu wolności budowlanej, której adresatem był inwestor, względem ochrony interesu publicznego. Różny stopień zagrożenia dla interesu publicznego na określonym obszarze miał wpływ na odmienny sposób uregulowania miejscowych przepisów budowlanych.

Przepisy miejscowe dotyczyły m.in. warunków zagospodarowania terenu ${ }^{18}$, warunków technicznych procesu budowlanego ${ }^{19}$, warunków technicznych obiektu

${ }^{13}$ M. Błażewski, Zasada wolności budowlanej w procesie budowlanym. Studium administracyjnoprawne, Wrocław 2016, s. 31.

${ }^{14}$ W. Szwajdler, op. cit., s. 135.

15 W. Brzeziński, op. cit., s. 32; A. Ostrowska, Pozwolenie na budowę, Warszawa 2009, s. 16.

${ }^{16}$ C. Krawczak, op. cit., s. 122; D. Sypniewski, op. cit., s. 154.

17 W. Brzeziński, op. cit., s. 32; C. Krawczak, op. cit., s. 124.

${ }_{18}$ Miejscowe przepisy budowlane regulujące warunki zagospodarowania terenu mogły dotyczyć m.in.: szerokości i sposobu urządzania ulic, placów i dróg w osiedlach (art. 408 pkt 1 r.p.b.z.o.); rozmiaru działki budowlanej i sposobu połączenia działki z ulicą lub drogą (art. 408 pkt 2 r.p.b.z.o.); rozmiaru niezabudowanej przestrzeni i podwórza na działce budowlanej oraz sposobu urządzenia podwórza (art. 408 pkt 3 oraz art. 409 pkt 3 r.p.b.z.o.); sposobu urządzenia otworów w ścianach zewnętrznych i sposobu zawieszania i wystawiania m.in. szyldów, witryn i napisów reklamowych (art. 408 pkt 6 r.p.b.z.o.); dopuszczalności wznoszenia budynków ogniotrwałych w miastach (art. 408 pkt 4 r.p.b.z.o.); sposobu wykonania części budynków widocznych z ulic, dróg i placów (art. 408 pkt 7 r.p.b.z.o.); dopuszczalności budowy suteren przeznaczonych na pobyt ludzi (art. 408 pkt 10 r.p.b.z.o.); sposobu odgradzania posiadłości i działek od strony ulic, placów oraz przyległych posiadłości i działek (art. 408 pkt 13 r.p.b.z.o.); odległości budynków od ulic, dróg, granic sąsiadów oraz innych budynków (art. 409 pkt 1 r.p.b.z.o.); połączenia podwórzy i budynków z ulicą lub drogą (art. 409 pkt 2 r.p.b.z.o.); zakazu wznoszenia budynków mieszkalnych w miastach przy ulicach nieurządzonych (art. 410 pkt 1 r.p.b.z.o.); zakazu wznoszenia, przy ulicach i placach o historycznym lub artystycznym znaczeniu, budynku mogącego zmienić odrębny charakter ulicy lub placu (art. 410 pkt 2 r.p.b.z.o.); najmniejszej dopuszczalnej wysokości budynków w dzielnicach lub przy ulicach (art. 410 pkt 3 r.p.b.z.o.); obowiązku wznoszenia obór, stajen i chlewów w dzielnicach osiedli (art. 410 pkt 8 r.p.b.z.o.); obowiązku przyłączenia działek do gminnej sieci wodociągowej i kanalizacyjnej (art. 410 pkt 9 r.p.b.z.o.)

${ }^{19}$ Miejscowe przepisy budowlane dotyczące warunków technicznych procesu budowlanego zostaną omówione w dalszej części tego opracowania. 
budowlanego $0^{20}$ oraz udziału właścicieli nieruchomości w kosztach zagospodarowania terenu ${ }^{21}$. Przepisy te mogły wprowadzać odrębne regulacje dotyczące warunków technicznych procesu budowlanego, które obejmowały sposób budowy części budynków $^{22}$, krycia dachów ${ }^{23}$, budowy suteren i piwnic ${ }^{24}$, budowy studzien oraz urządzeń wodociągowych i kanalizacyjnych ${ }^{25}$, jak również warunki zajęcia w czasie wykonywania robót budowlanych części ulic i dróg, przyległych do budowy ${ }^{26}$. Miejscowe przepisy budowlane mogły także wprowadzać obostrzenia dotyczące warunków technicznych procesu budowlanego, które dotyczyły: budowy schodów, świetlików, fundamentów, pieców, kominów, pomieszczeń przeznaczonych na pobyt ludzi, studzien, ustępów, dołów ustępowych, gnojowników, obór, stajen i chlewów ${ }^{27}$. Przepisy te mogły ustanawiać obowiązek uzyskania pozwolenia na budowę, zgłoszenia budowy oraz poddania budynków w czasie budowy sprawdzeniu w stanie surowym ${ }^{28}$.

Miejscowe przepisy wydawał Minister Robót Publicznych, w porozumieniu z Ministrem Spraw Wewnętrznych. Były one wydawane na wniosek wojewody

${ }^{20}$ Miejscowe przepisy budowlane regulujące warunki techniczne obiektu budowlanego mogły dotyczyć m.in.: szczegółowych warunków budynków wznoszonych przy ulicach, drogach, placach (art. 408 pkt 7 r.p.b.z.o.); warunków pomieszczeń przeznaczonych na pobyt ludzi (art. 408 pkt 9 r.p.b.z.o.); dopuszczalności w drodze wyjątku urządzenia mieszkań w suterenach (art. 408 pkt 10 r.p.b.z.o.); sposobu urządzania obór, stajen, chlewów, składów na drewno i innych budynków gospodarskich (art. 408 pkt 11 r.p.b.z.o.); sposobu urządzania łazienek, ustępów, gnojowników i tym podobnych urządzeń (art. 408 pkt 12 r.p.b.z.o.); warunków należytego utrzymania budynków ze względu na bezpieczeństwo od ognia oraz warunków czyszczenia kominów (art. 408 pkt 15 r.p.b.z.o.); wysokości budynków (art. 409 pkt 4 r.p.b.z.o.); długości i wysokości budynków nieogniotrwałych oraz innych warunków tych budynków (art. 409 pkt 5 r.p.b.z.o.); warunków, którym powinny odpowiadać budynki cofnięte od zatwierdzonej linii zabudowania, oraz budynki przekraczające normalną wysokość (art. 410 pkt 4 r.p.b.z.o.); obowiązku urządzania dźwigów w domach o większej liczbie kondygnacji (art. 410 pkt 6 r.p.b.z.o.); zakazu pokrywania dachów materiałami nieogniotrwałymi w miejscowościach wiejskich (art. 410 pkt 7 r.p.b.z.o.); zasad i warunków ogólnych oraz technicznych przyłączenia działek do gminnej sieci wodociągowej i kanalizacyjnej (art. 410 pkt 9 r.p.b.z.o.).

${ }^{21}$ Miejscowe przepisy budowlane regulujące udział właścicieli nieruchomości w kosztach zagospodarowania terenu mogły dotyczyć m.in.: zasad przełożenia na właścicieli przyległych działek kosztów urządzania ulic w miastach i uzdrowiskach, które miały charakter użyteczności publicznej (art. 408 pkt 1 r.p.b.z.o.); obowiązku i zasad udziału właścicieli działek, które nie przylegały do nowo utworzonych ulic, w pokryciu kosztów urządzenia ulic (art. 410 pkt 5 r.p.b.z.o.); sposobu pokrycia kosztów przyłączenia działek do gminnej sieci wodociągowej i kanalizacyjnej oraz opłat za pobór wody z gminnego wodociągu i za korzystanie z kanalizacji (art. 410 pkt 9 r.p.b.z.o.).

22 Zgodnie z art. 408 pkt 5 r.p.b.z.o. miejscowe przepisy budowlane mogły uregulować sposób budowy fundamentów, ścian i innych części budynków. Zgodnie z art. 408 pkt 6 r.p.b.z.o. miejscowe przepisy budowlane mogły uregulować sposób budowy m.in. ganków i wykuszy.

${ }^{23}$ Art. 408 pkt 8 r.p.b.z.o.

24 Art. 408 pkt 10 r.p.b.z.o.

25 Art. 408 pkt 14 r.p.b.z.o.

26 Art. 408 pkt 16 r.p.b.z.o.

27 Art. 409 pkt 6-11 r.p.b.z.o.

${ }^{28}$ Art. 410 pkt $10-11$ r.p.b.z.o. 
lub, w przypadku Warszawy, na wniosek magistratu ${ }^{29}$. Te naczelne organy administracji publicznej mogły łącznie, w drodze rozporządzenia, przekazać wojewodom uprawnienia do wydawania tych przepisów ${ }^{30}$.

Wolność budowlana była ograniczona także ze względu na ochronę interesu prawnego osoby trzeciej. Ograniczenie to dotyczyło sfery rozpoczęcia procesu budowlanego. Interes ten był wyrażony m.in. w postępowaniu w sprawie pozwolenia na budowę. Przepisy prawa zawarte w rozporządzeniu Prezydenta RP nie naruszały praw osób trzecich, które służyły im w zakresie prawa prywatnego oraz dochodzenia ich praw na drodze sądowej ${ }^{31}$. Ochrona interesów indywidualnych osób trzecich była zatem ograniczona przez rozdzielenie środków tej ochrony pomiędzy postępowanie administracyjne i postępowanie przed sądem powszechnym.

Ograniczenia wolności budowlanej były zapewnione przez organ władzy budowlanej wykonującej nadzór policyjno-budowlany, który obejmował rozpoczęcie oraz organizację procesu budowlanego. Nadzór ten był rodzajem policji gospodarczej, „wyodrębnionym ze względu na kryterium przedmiotowe"32. Nadzór policyjno-budowlany oznaczał czynności prawne podejmowane w celu ochrony życia, zdrowia, mienia oraz porządku publicznego ${ }^{33}$. Nadzór ten miał tym samym na celu ochronę interesu publicznego.

Nadzór policyjno-budowlany wykonywały organy władzy budowlanej, do której należeli m.in.: wojewoda ${ }^{34}$, magistraty miast oraz zwierzchności gmin miejskich $^{35}$, wydziały wykonawcze komisji uzdrowiskowych ${ }^{36}$, wydziały powiatowe $^{37}$, starosta ${ }^{38}$, zarządy gmin wiejskich ${ }^{39}$ oraz Minister Komunikacji ${ }^{40}$. Organami władzy budowlanej drugiej instancji byli: wojewoda ${ }^{41}$, Minister Robót Publicznych ${ }^{42}$, Minister Przemysłu i Handlu ${ }^{43}$. Właściwość organów władzy budowlanej zależała od rodzaju obiektu budowlanego (m.in.: świątynie, budynki przeznaczone do użytku publicznego ${ }^{44}$, parterowe budynki mieszkalne, budyn-

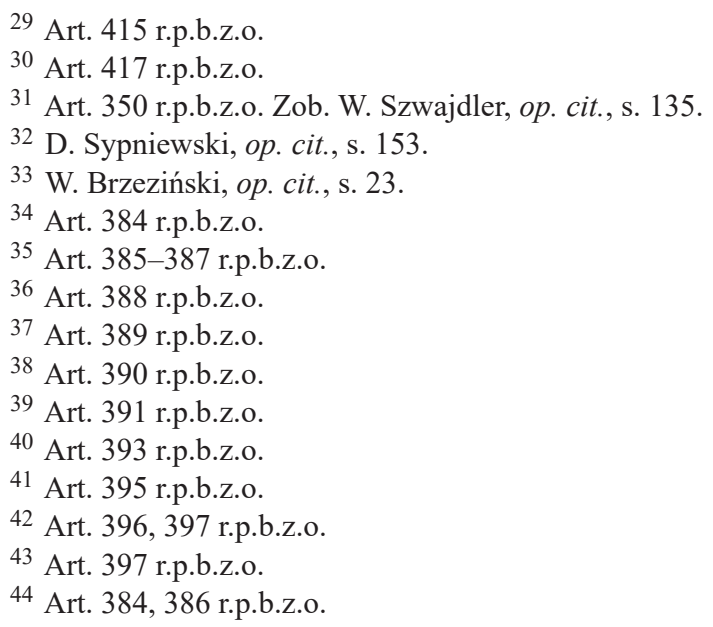


ki gospodarskie ${ }^{45}$ ), właściciela obiektu budowlanego (obiekty prywatne, samorządowe oraz państwowe), położenia obiektu budowlanego (obiekty położone w: uzdrowiskach ${ }^{46}$, miejscowościach wiejskich ${ }^{47}$, strefie nadgranicznej ${ }^{48}$ ).

\section{Ograniczenie swobody rozpoczęcia procesu budowlanego}

Rozpoczęcie procesu budowlanego zależało z zasady od woli inwestora. Swoboda rozpoczęcia tego procesu była jednak ograniczona w celu ochrony interesu publicznego oraz interesu prawnego osób trzecich ${ }^{49}$. Środkami reglamentującymi wykonywanie robót, które ograniczały swobodę inwestora, były:

1. pozwolenie na budowę po zatwierdzeniu projektu ${ }^{50}$,

2. pozwolenie na budowę bez wymogu przedstawienia projektu ${ }^{51}$,

3. zgłoszenie budowy ${ }^{52}$.

Pozwolenie na budowę obejmowało wykonywanie robót budowlanych polegających na budowie lub rozbiórce obiektu budowlanego. Władza nadzoru budowlanego, wydając pozwolenie na budowę, była obowiązana uwzględnić ochronę krajobrazu ${ }^{53}$.

Pozwolenie na budowę mogło dotyczyć także rozbiórki obiektu budowlanego. Rozbiórka zabytkowego obiektu budowlanego wymagała uzyskania przez osobę interesowaną pozwolenia określonego w przepisach o opiece nad zabytkami sztuki i kultury ${ }^{54}$.

Przepisy wyrażone w rozporządzeniu wprowadzały dodatkowe wymagania wobec pozwolenia na budowę obiektu budowlanego w pobliżu szczególnych obiektów ${ }^{55}$ lub pozwolenia na budowę szczególnego rodzaju obiektu.

Organy władzy budowlanej pełniły nadzór nad rozpoczęciem procesu budowlanego przez obowiązek zatwierdzania projektów budowlanych, wydawania po-

45 Art. 391 r.p.b.z.o.

46 Art. 388 r.p.b.z.o.

${ }^{47}$ Art. 389 r.p.b.z.o.

48 Art. 390 r.p.b.z.o.

${ }^{49}$ M. Błażewski, op. cit., s. 31.

${ }^{50}$ Art. 333 r.p.b.z.o.

${ }^{51}$ Art. 334 r.p.b.z.o.

52 Art. 335 r.p.b.z.o.

53 Art. 337 r.p.b.z.o.

${ }^{54}$ Art. 341 r.p.b.z.o.

55 Przepisy budowlane określały dodatkowe wymagania wobec obiektów budowlanych wznoszonych w pobliżu twierdzy, rejonu fortyfikacyjnego (art. 342 r.p.b.z.o.) oraz kolei żelaznej (art. 345 r.p.b.z.o.). 
zwolenia na budowę oraz milczącej zgody na wykonywanie zgłoszonej budowy ${ }^{56}$. Nadzór nad rozpoczęciem tego procesu umożliwiał tym organom prewencyjną kontrolę robót budowlanych ${ }^{57}$. Organy te miały prawo wstrzymać roboty budowlane, które były prowadzone bez wymaganego pozwolenia na budowę ${ }^{58}$. Kontynuowanie robót budowlanych było warunkowane uzyskaniem pozwolenia na budowę ${ }^{59}$.

\section{Ograniczenie swobody organizacji procesu budowlanego}

Ograniczenie wolności budowlanej obejmowało także swobodę inwestora związaną z organizacją procesu budowlanego. Przepisy prawa wprowadzały te ograniczenia, nakładając na inwestora obowiązek ustanowienia podmiotów procesu budowlanego oraz przestrzegania warunków bezpieczeństwa dotyczących robót budowlanych i obiektu budowlanego.

Podmiotami procesu budowlanego byli projektant oraz kierownik robót budowlanych. Projektant był podmiotem wykonującym projekt lub plan wymagany przez przepisy prawa ${ }^{60}$. Inwestor miał obowiązek powołać projektanta, jeżeli roboty budowlane były prowadzone na podstawie pozwolenia na budowę po zatwierdzeniu projektu ${ }^{61}$. Kierownik robót budowlanych sprawował nadzór techniczny nad procesem budowlanym ${ }^{62}$. Osoba interesowana miała obowiązek powołać kierownika robót budowlanych, jeżeli roboty były wykonywane na podstawie pozwolenia na budowę po zatwierdzeniu projektu ${ }^{63}$ lub jeżeli roboty zagrażające bezpieczeństwu publicznemu były wykonywane na podstawie pozwolenia na budowę bez wymogu przedstawienia projektu ${ }^{64}$. Przepisy rozporządzenia wprowadzały ograniczenia dotyczące projektanta oraz kierownika robót budowlanych. Powinni oni byli posiadać kwalifikacje umożliwiające skuteczne prowadzenie procesu budowlanego ${ }^{65}$. Kwalifikacje były potwierdzone uprawnieniami budowlanymi udzielonymi przez Ministra Robót Publicznych ${ }^{66}$. Projektant oraz

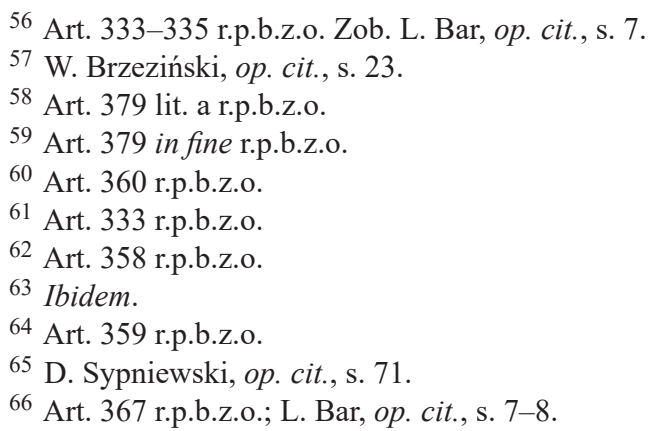


kierownik robót budowlanych byli obowiązani posiadać odpowiednie wykształcenie i doświadczenie zawodowe oraz zdany egzamin ${ }^{67}$.

Ograniczenia organizacji procesu budowlanego dotyczyły także warunków bezpieczeństwa. Warunki te dotyczyły m.in. rusztowań, wykopów, dołów, urządzeń przy budowie oraz robót murarskich i betoniarskich ${ }^{68}$.

Organy władzy budowlanej sprawowały nadzór nad wykonywanymi robotami budowlanymi zgodnie $\mathrm{z}$ tymi ograniczeniami procesu budowlanego przez wydawanie nakazów i zakazów ${ }^{69}$. Nadzór nad organizacją procesu budowlanego dotyczył badania wykonywania robót budowlanych w sposób zgodny z przepisami prawa, zasadami sztuki budowlanej oraz w celu zapobieżenia zagrożeniom dla bezpieczeństwa życia i zdrowia ludzkiego ${ }^{70}$.

Nadzór policyjno-budowlany obejmował także działania organów władzy budowlanej polegające na wydawaniu aktów administracyjnych: wstrzymujących roboty budowlane, nakazujących dokonanie przeróbek lub rozbiórkę obiektu budowlanego ${ }^{71}$. Organy władzy budowlanej miały prawo wstrzymać roboty budowlane prowadzone ze zmianami, nieprzewidzianymi w pozwoleniu na budowę ${ }^{72}$. Inwestor mógł kontynuować wykonywanie robót budowlanych po uzyskaniu pozwolenia na budowę ${ }^{73}$. Organy władzy budowlanej mogły także wstrzymać roboty budowlane, jeżeli roboty były prowadzone w sposób mogący spowodować niebezpieczeństwo dla życia albo zdrowia ludzkiego ${ }^{74}$. Organy władzy budowlanej określały wówczas warunki, od których uzależniały dalsze wykonywanie robót budowlanych ${ }^{75}$.

\section{Zakończenie}

Regulacje procesu budowlanego, wyrażone w rozporządzeniu z 1928 r., miały istotne znaczenie dla rozwoju sektora budownictwa w II Rzeczypospolitej Polskiej. Rozporządzenie Prezydenta RP zawierało jednolitą regulację prawa budowlanego, a jednocześnie odpowiadało warunkom gospodarki kapitalistycznej. Roboty budowlane były wykonywane w większości przez prywatnych przedsiębiorców. Proces budowlany opierał się na wolności budowlanej wynikającej z prawa własności nieruchomości gruntowej.

${ }^{67}$ Art. 361-364 r.p.b.z.o.

${ }^{68}$ Art. 372-374 r.p.b.z.o. Warunki bezpieczeństwa określały także akty wykonawcze (art. 375376 r.p.b.z.o.).

\footnotetext{
${ }^{69}$ L. Bar, op. cit., s. 7; C. Krawczak, op. cit., s. 124.

${ }^{70}$ Art. 378 r.p.b.z.o.

71 A. Ostrowska, op. cit., s. 16.

72 Art. 379 lit. b r.p.b.z.o.

${ }^{73}$ Art. 379 in fine r.p.b.z.o.

74 Art. 379 lit. c r.p.b.z.o.

${ }^{75}$ Art. 379 in fine r.p.b.z.o.
} 
Zapewnienie wolności budowlanej, której adresatem był inwestor, było konieczne ze względu na cel tych regulacji, związany z umożliwieniem rozwoju gospodarczego i społecznego przez wykonywanie zamierzeń budowlanych. Ułatwienia dla inwestora wynikające $\mathrm{z}$ wolności budowlanej były względne, ponieważ regulacje rozporządzenia Prezydenta RP ograniczały swobodę inwestora względem rozpoczęcia i organizacji procesu budowlanego.

Po II wojnie światowej, pomimo zmian warunków gospodarczych, przepisy prawa określające zakres wolności budowlanej zostały zmienione dopiero wraz z uchwaleniem ustawy z 1961 r. Prawo budowlane ${ }^{76}$. Ustawa ta częściowo ograniczała wolność budowlaną, poszerzając zakres ochrony interesu publicznego (społecznego ${ }^{77}$. W latach $1944-1961$ prawodawca pozostawił dotychczasowe regulacje dotyczące zakresu wolności budowlanej, ograniczając się do zmiany przepisów pośrednio związanych z procesem budowlanym, w tym regulacji dotyczących planów inwestycyjnych ${ }^{78}$. Wolność budowlana przysługiwała nadal, lecz ze względu na zmianę stosunków własnościowych zamierzenia budowlane były realizowane w przeważającej mierze przez podmioty państwowe i społeczne. Podmioty prywatne, które najczęściej wykonywały zamierzenia budowlane przed II wojną światową, po zmianie ustrojowej straciły swoją dominującą pozycję.

\section{Bibliografia}

\section{Źródła}

Rozporządzenie Prezydenta Rzeczypospolitej z dnia 16 lutego 1928 r. o prawie budowlanem i zabudowaniu osiedli (Dz.U. $1928 \mathrm{Nr} 23$, poz. 202).

Dekret z dnia 25 czerwca 1946 r. o państwowym planie inwestycyjnym (Dz.U. Nr 32, poz. 200). Ustawa z dnia 31 stycznia 1961 r. Prawo budowlane (Dz.U. 1961 Nr 7, poz. 46).

\section{Literatura}

Bar L., Podstawowe zasady prawa budowlanego, Warszawa 1963.

Błażewski M., Zasada wolności budowlanej w procesie budowlanym. Studium administracyjnoprawne, Wrocław 2016.

Brzeziński W., Polskie prawo budowlane, Warszawa 1955.

Jędrzejewski S., Proces budowlany. Zagadnienia administracyjno-prawne, Bydgoszcz 1995.

76 Ustawa z dnia 31 stycznia 1961 r. Prawo budowane (Dz.U. 1961 Nr 7, poz. 46).

77 Problematyka ustawy Prawo budowlane z 1961 r. stanowi odrębny przedmiot badań, wykraczający poza analizowaną $\mathrm{w}$ tym opracowaniu problematykę badawczą.

78 Regulacje dotyczące zapewnienia środków na cele związane z realizacją zamierzeń budowlanych zostały wyrażone m.in. w Dekrecie z dnia 25 czerwca 1946 r. o państwowym planie inwestycyjnym (Dz.U. Nr 32, poz. 200). 
Kisilowska H., Sypniewski D., Prawo budowlane, Warszawa 2012.

Krawczak C., Prawo budowlane na ziemiach polskich od połowy XVIII wieku do 1939 roku, Poznań 1975.

Ostrowska A., Pozwolenie na budowę, Warszawa 2009.

Sypniewski D., Nadzór nad procesem budowlanym, Warszawa 2011.

Szwajdler W., Prawne problemy procesu budowlanego, [w:] W. Szwajdler, T. Bąkowski, Proces inwestycyjno-budowlany. Zagadnienia administracyjno-prawne, Torun 2004.

\title{
Limitations of the freedom of construction in the ordinance of the President of Poland of 1928 on construction law and development of residential estates
}

\author{
Summary
}

The Ordinance of the President of 1928 on the construction law and housing developments had unified regulations on the construction process. Provisions have balanced the freedom of the construction and the public interest and interests of the individual person. These provisions provided the primacy of the public interest in relation to the interest of the individual person. The regulations concerned the initiation and organization of the construction process. struction

Keywords: The construction process, the investor, the public interest, the freedom of the con-

\section{Die Einschränkung der Baufreiheit nach der Verordnung des Präsidenten der Republik Polen aus dem Jahre 1928 über das Baurecht und die Bebauung von Ortschaften}

\section{Zusammenfassung}

Die Verordnung aus dem Jahre 1928 über das Baurecht und die Bebauung von Ortschaften vereinheitlichte die Regelungen betreffend den Bauprozess. Die Rechtsvorschriften führten zur Ausgewogenheit der Baufreiheit gegenüber dem öffentlichen Interesse und dem Interesse einer individuellen Drittperson. Die Vorschriften sicherten die Vorherrschaft des öffentlichen Interesses gegenüber dem individuellen Interesse. Die die Baufreiheit einschränkenden Regelungen betrafen den Beginn und die Organisation des Bauprozesses.

Schlüsselworte: Bauprozess, Bauherr, öffentliches Interesse, Baufreiheit 